\title{
Use of Plastic Waste in Flexible Pavement-Green Highway
}

\author{
Prashant Singh ${ }^{1}$, Abhishek Kumar ${ }^{2}$, Shushant Singh ${ }^{3}$, \\ Rajeev Rajput ${ }^{4}$$$
{ }_{1,2,3,4} \text { M. Tech }
$$ \\ Department of Civil Engineering \\ J.S. University, Shikohabad, Firozabad, India
}

\author{
Chhabi Lal Singh ${ }^{5}$ \\ ${ }^{5}$ Assistant Professor \\ Department of Civil Engineering \\ J.S. University, Shikohabad, Firozabad, India
}

\begin{abstract}
Today, plastic waste and its disposal Such as wrappers of chocolate, chips, carry bags, cold drink bottles and all other forms of plastic create significant environmental and economic problems. These forms of plastic consume massive energy-depleting in the environment in various ways. So manufacturing firms and construction industries, the use of plastic is a priority to handle and pack things comfortable due to its lightweight, effectiveness cost, and strength. The plastic waste used is poly-ethylene, poly-styrene, poly-propylene, the temperature varying between $120^{\circ} \mathrm{c}-160^{\circ} \mathrm{c}$ gives the softening point of these plastics. The plastic waste is shredded $\&$ coated over the aggregate and mixed with hot bitumen and the resulted mix is used for pavement construction this mix will not only strengthen the pavement and also increases its durability. The main objective of this paper is to discuss the importance of plastic in terms of cost reduction, increases the strength and durability when these plastics are heated and coated upon the aggregates to reduce the air voids with plastic and binds with aggregate to provide stability. It's economical and eco-friendly.
\end{abstract}

Keywords-Flexible pavement, aggregate, plastic waste, plastic modified bitumen and plastic modified aggregate

\section{INTRODUCTION}

In India have many problems with the disposal of plastic waste and it's very dangerous for human health and animals also, the availability of the waste plastics is enormous, as the plastic materials have become a parcel of daily life. If it is not recycled, their present disposal is either by land filling or by incineration. Then both these processes have a certain impact on the environment. So we got an idea the plastic waste is used in road construction. India is using waste plastic in road construction is relatively new. The laboratory tests have shown positive results when a small amount (5 to $10 \%$ by weight of plastic is incorporated in bituminous mixes asphalt), resulting in improvement pavement stability, strength, and durability. Plastic can be divided into two major categoriesthermoses \& thermoplastics. Thermoses have high durability and strength because it solidifies irreversibly when heated, henceforth can be used primarily in construction application. Plastic is a non-degradable waste, causes the greenhouse effect and global warming. The different experiments have been carried out whether the waste plastic can be reused productively. The various literature indicated that the waste plastic when added to hot aggregates, will form a fine coat of plastic over the aggregate, and such aggregates when mixed with a binder is found to have higher strength, higher resistance, and better performance over some time. It is economical and eco-friendly. India has promoted the use of waste plastic in flexible pavement mixes for the construction of its National Highways and Rural roads and has approved it as a default mode of periodic renewal with a hot mix for roads within $50 \mathrm{~km}$ periphery of urban areas with more than 50000 Population (Government of India, 2015; National Rural Road Development Agency, 2019). The Indian Road Congress (2013) has published guidelines for the use of waste plastic in hot bituminous mixes while National Rural Road Development Agency.

\section{LITERATURE REVIEW}

The use of plastic waste in flexible pavements would open up a solution for the disposal issues regarding plastics wastes. Many research works have been done in the area of use of plastic waste in bituminous road construction.

Dr. R. Vasudevan (2007) is an Indian scientist who has worked mainly in waste management. This method will help in making roads very faster and also will save the environment from dangerous plastic waste. He is also visited mahatma school on 15 April 2008. The road also shows greater resistance to damage caused by heavy rains. His road construction method is now widely used to construction Roads in the rural area. Dr. R. Vasudevan was awarded India's fourth-highest civilian Honour Padma Shri.

Amit Gawande (2012) The concept of utilization of waste plastic in the construction of flexible road pavement has been done since 2000 in India. In the construction of flexible pavements, bitumen plays the role of coating over the aggregate and binding the aggregate together. It also helps to improve the strength and life of road pavement. But its resistance towards water is poor. It is a method to enhance the quality of bitumen by modifying the chemical properties of bitumen by blending with synthetic polymers. The use of plastic waste in the bitumen is similar to polymer-modified bitumen.

\section{SCOPE}

- To eradicate potholes.

- To minimize global warming, greenhouse gases, and pollution.

- The lifespan of the roads can be increased.

- Eco-friendly in nature.

\section{OBJECTIVES}

This study is conducted with the main objective.

- Reducing the plastic waste present in our environment and making solid waste management better. 
- To carry out the soil test.

- To reduce the cost of road construction.

- To design the flexible pavement.

- To increasing the various properties of road materials.

- To design the asphalt pavement with the aggregateplastic-bitumen mix.

- To prepare a statistical model for the optimum utilization of plastic waste.

- To coat the aggregate with plastic and incorporate titanium dioxide.

\section{METHODOLOGY}

A. Use of Materials

a) Bitumen - 60/70,80/100 grade bitumen was used for the present study the important quality of bitumen which has made bitumen a popular material is its excellent binding property and get soften when heated. The bitumen for bituminous mixes for wearing course with waste plastic shall comply with the Indian Standard Specifications for viscosity graded paving bitumen IS 73. Guidelines for selection for the grade of viscosity graded paving bitumen shall be under the IRC:111-2009.

TABLE I. VISCOSITY OF 80-100, 60-70 AND PG 76 GRADED NEAT ASPHALT BINDER

\begin{tabular}{|c|c|c|c|}
\hline \multirow[b]{2}{*}{$\begin{array}{l}\text { Type of } \\
\text { asphalt }\end{array}$} & \multicolumn{2}{|c|}{ Viscosity, cP } & \multirow{2}{*}{$\begin{array}{c}\text { Ratio of } \\
\text { Viscosity } \\
1^{0}{ }^{0} \mathrm{C} / 165 \mathrm{C}\end{array}$} \\
\hline & $\begin{array}{c}A t \\
{ }_{135}{ }^{\circ} C\end{array}$ & $\begin{array}{c}A t \\
0 \\
165\end{array}$ & \\
\hline $80-100$ & 268.7 & 106 & 3.47 \\
\hline $60-70$ & 425 & 150 & 2.83 \\
\hline PG 76 & 1600 & 675 & 2.37 \\
\hline
\end{tabular}

b) Aggregate - The aggregate is one of the important materials used for flexible pavement construction. The property selected and graded aggregates are mixed with bitumen to form hot mix asphalt (HMA) pavement. Two types of aggregate are used like course \& fine and size used $20 \mathrm{~mm}$ and $10 \mathrm{~mm}$.

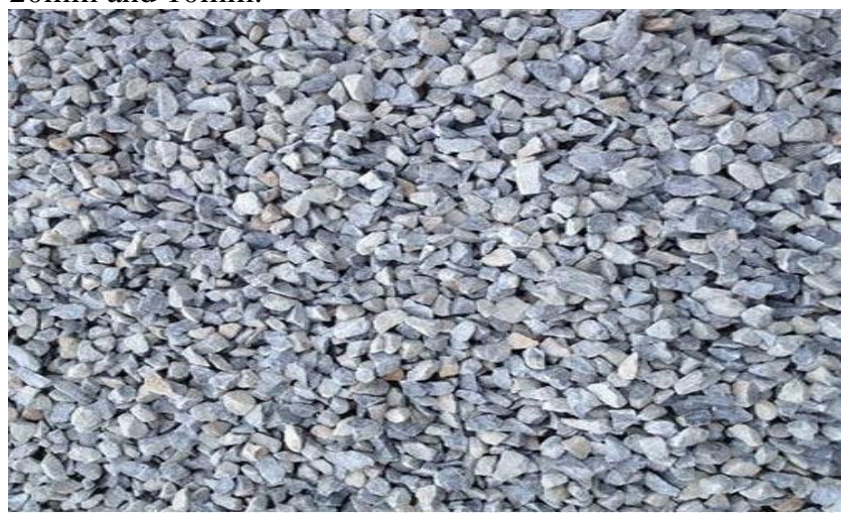

Fig. 1. $10 \mathrm{~mm}$ course aggregate

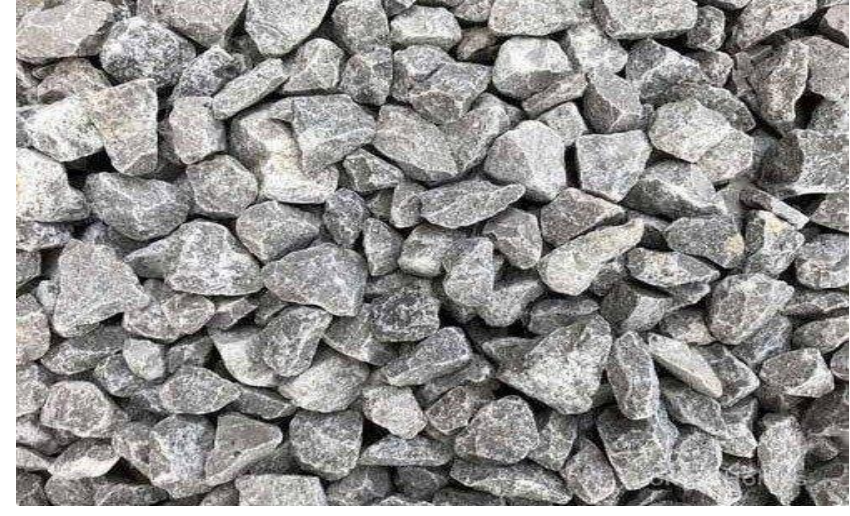

Fig. 2. $20 \mathrm{~mm}$ course aggregate

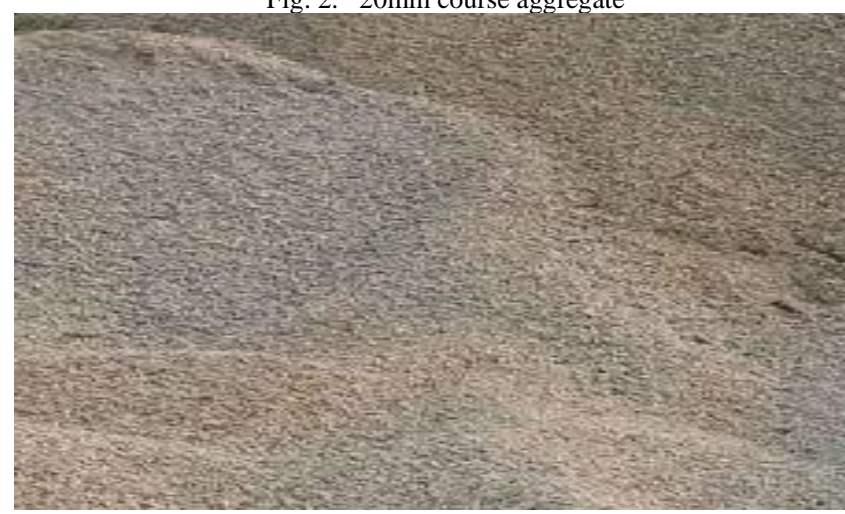

Fig. 3. Fine aggregate

c) Filler - The filler for dense graded mixes shall comply with IRC :111-2009. $6 \mathrm{~mm}$ and stone dust \& lime Used as filler.

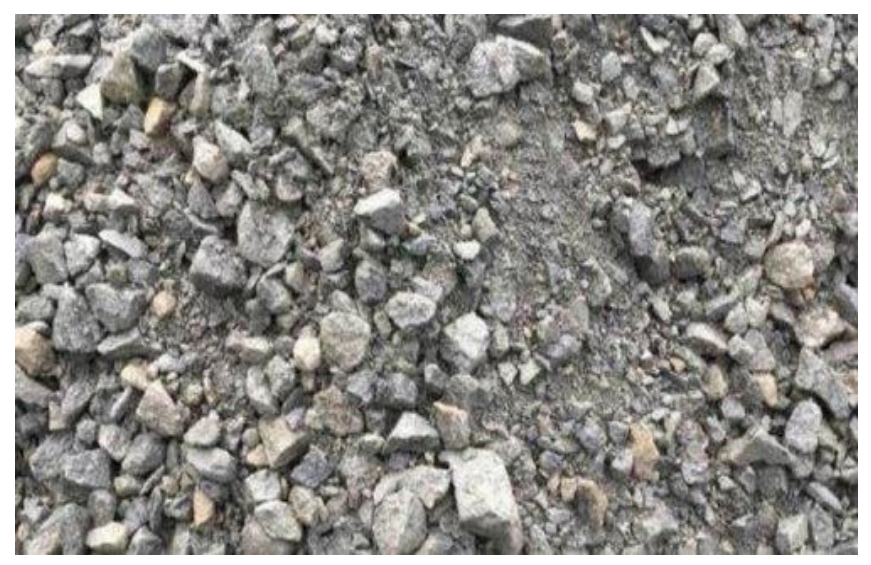

Fig. 4. $6 \mathrm{~mm}$ filler

d) Waste plastic - Plastic is one of the materials which enhanced its binding property when softened, Hence, this softened plastic material can be used as an effective binder in bitumen.

- The plastic waste shall conform to the size passing $2.36 \mathrm{~mm}$ sieve and retained on 600 micron sieve.

- Dust and other impurities shall not be more than 1 percent.

- To make out the ability of plastic to mix with the binder, the melt-flow value shall be tested as per 
ASTM D 1238-2010, for which the range shall be as follows:

For LDPE: $0.14-58 \mathrm{gm} / 10 \mathrm{~min}$

For HDPE: 0.02-9.0 gm/10 min

TABLE II. WASTE PLASTIC AND ITS SOURCE

\begin{tabular}{|c|c|}
\hline Waste Plastic & Origin \\
\hline Low-Density Polyethylene (LDPE) & $\begin{array}{l}\text { Carry bags, sacks, milk pouches, } \\
\text { bin lining, cosmetic, and detergent } \\
\text { bottles. }\end{array}$ \\
\hline High-Density Polyethylene (HDPE) & $\begin{array}{l}\text { Carry bags, bottle caps, household } \\
\text { articles, etc. }\end{array}$ \\
\hline Polyethylene Terephthalate (PET) & Drinking water bottles etc. \\
\hline Polypropylene (PP) & $\begin{array}{l}\text { Bottle caps and closures, } \\
\text { wrappers of detergent, biscuit, } \\
\text { wafer packets, microwave trays } \\
\text { for the readymade meal, etc. }\end{array}$ \\
\hline Polystyrene (PS) & $\begin{array}{l}\text { Yogurt pots, clear egg packs, } \\
\text { bottle caps. Foamed Polystyrene: } \\
\text { food trays, egg boxes, disposable } \\
\text { cups, protective packaging, etc. }\end{array}$ \\
\hline Polyvinyl Chloride (PVC) & $\begin{array}{l}\text { Mineral water bottles, credit } \\
\text { cards, toys, pipes and gutters; } \\
\text { electrical fittings, furniture, } \\
\text { folders and pens, medical } \\
\text { disposables; etc. }\end{array}$ \\
\hline
\end{tabular}

\section{B. Design Mix}

a) Dense graded mixes - The properties for dense graded mixes are indicated in table-III.

TABLE III. REQUIREMENTS FOR WASTE PLASTIC MODIFIED DENSE GRADED BITUMINOUS PAVEMENT LAYERS

\begin{tabular}{|l|c|}
\hline Minimum stability (kN at $\left.60^{\circ} \mathrm{C}\right)$ & 12.0 \\
\hline Minimum flow (mm) & 2 \\
\hline Maximum flow (mm) & 4 \\
\hline Marshall Quotient (KN/mm) & $2.5-5$ \\
\hline $\begin{array}{l}\text { Compaction level (Number of } \\
\text { blows) }\end{array}$ & $\begin{array}{c}\text { 75 blows on each of the two faces of } \\
\text { the specimen }\end{array}$ \\
\hline Percent air voids & $3-5$ \\
\hline Retained stability (\%) & 98 \\
\hline ITS (min) MPa & 0.9 \\
\hline VMA & 16 \\
\hline VFB & $65-75$ \\
\hline $\begin{array}{l}\text { Quantity of waste plastic \% by } \\
\text { weight of plastic }\end{array}$ & $\begin{array}{c}\text { 6 to 8 depending on low rainfall or } \\
\text { high rainfall areas }\end{array}$ \\
\hline
\end{tabular}

b) Open graded mixes - Waste Plastic 6 to 8 percent of the weight of the bitumen can be used for Open-Grade Premix Surfacing and Mix Seal surfacing mix. The quantity of bitumen can be reduced correspondingly. An open graded cold mix is a coarse aggregate mix (very small amount of fine aggregate) with a large number of air voids to allow for water to drain. These mixes can be used as a surface course and show excellent resistance to fatigue, reflection cracking, rutting, and shoving. Open-graded mixes are useful for restoration at varying depths, either mixed in place or stockpiled

\section{Manufacturing of Bituminous Mix Using Waste Plastic}

Bituminous hot mixes using waste plastic for road construction are manufactured using either a 'dry' process or a 'wet' process. The dry process is considered to be simple, economical, and environmentally friendly, while the wet process requires more investment and machinery, and hence is not commonly used.

The scope of the present guidelines is restricted to the dry process only for the following reasons;

- Plastic is coated over stones improving the surface property of aggregates.

- The coatings easy \& the temperature required is the same as road laying temp.

- Use waste should be 6-8 percent by weight of bitumen depending on the climatic conditions of high and low rainfall areas.

- Flexible films of all types of plastics can be used.

- Doubles the binding property of aggregates.

- No new equipment is required.

- Bitumen bonding is stronger than normal.

- The coated aggregates show increased Stability of the mixes.

- Better performance after construction is based on the experience gained for medium-level city traffic.

- No evolution of any toxic gases as maximum temperature is $180^{\circ} \mathrm{C}$.

a) Dry process - In the dry process, the processed waste plastic is shredded and added to the hot aggregate (in figure6 , when lines $\mathrm{a}, \mathrm{b}$ and $\mathrm{d}$ are opened, keeping $\mathrm{c}$ and eclosed). The Indian Road Congress and National Rural Roads Development Agency. indicate that the shredded waste plastic size should preferably be $2-3 \mathrm{~mm}$ for better spread and coating on the aggregate. Dust and other impurities should not exceed $1 \%$. The shredded waste plastic is then added to the aggregates that are heated to $170^{\circ} \mathrm{C}$. The shredded waste plastic softens and melts to form a coating around the aggregates (Sahu and Singh, 2016). The bitumen is also heated to $160^{\circ} \mathrm{C}$, then the plastic-coated aggregates are mixed with bitumen and used for road construction.

In order to ensure that the quality of the finished waste plastic product is consistent the following process must be adhered to before considering its use in bituminous construction:

i. Collection of waste plastic.

ii. Cleaning and shredding of waste plastic.

iii. Shredding Machine.

iv. Mixing of shredded plastic waste, aggregate and bitumen in central mixing plant.

b) Wet process - In the wet process, the processed waste plastic in powder form is added to the hot bitumen (in figure 6 , when lines $\mathrm{c}$ and $\mathrm{e}$ are opened, and $\mathrm{a}, \mathrm{b}$ and $\mathrm{d}$ are closed).

The powdered waste plastic is directly mixed with bitumen before adding them to the aggregates. It has to be ensured that there is an even mix of plastic and bitumen, and the temperature range for this method is $155^{\circ} \mathrm{C}$ to $165^{\circ} \mathrm{C}$. Sahu and Singh (2016) suggest a 6-8\% of waste plastic powder within the bitumen mix 
c) Process Details -

i. Collection of waste plastic :- Waste plastic is collected from roads, garbage trucks, dumpsites or compost plants, or from school collection programs, or by purchase from rag- pickers or waste-buyers

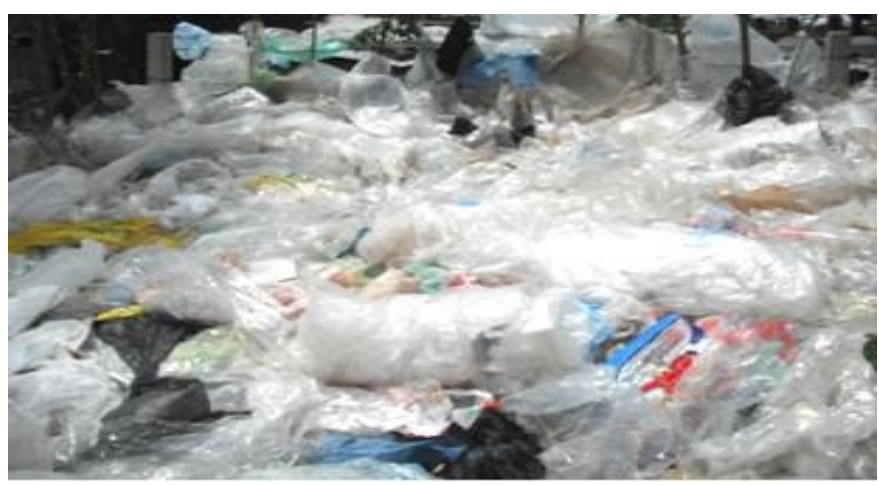

Fig. 5. Collection of waste plastic
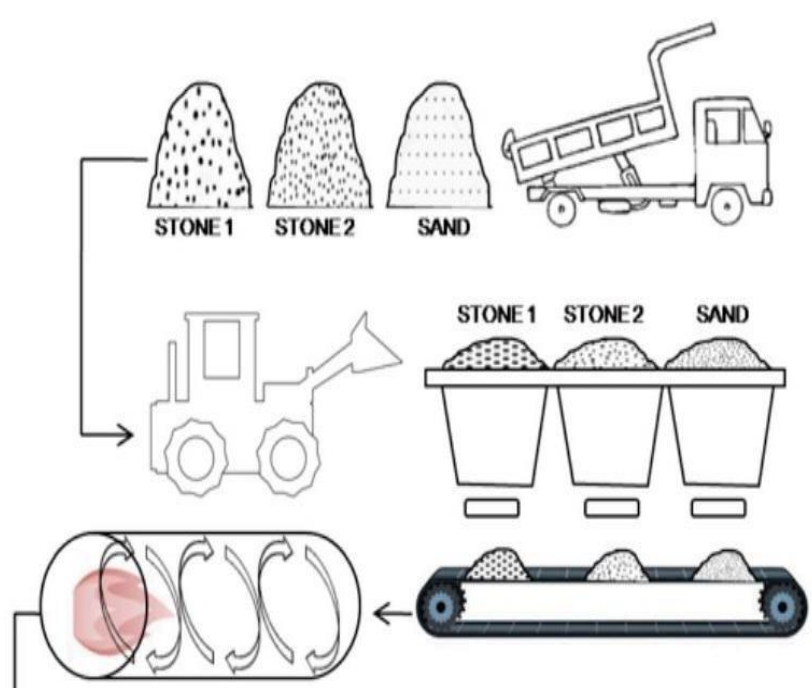

ROTARYDRIM DRYER

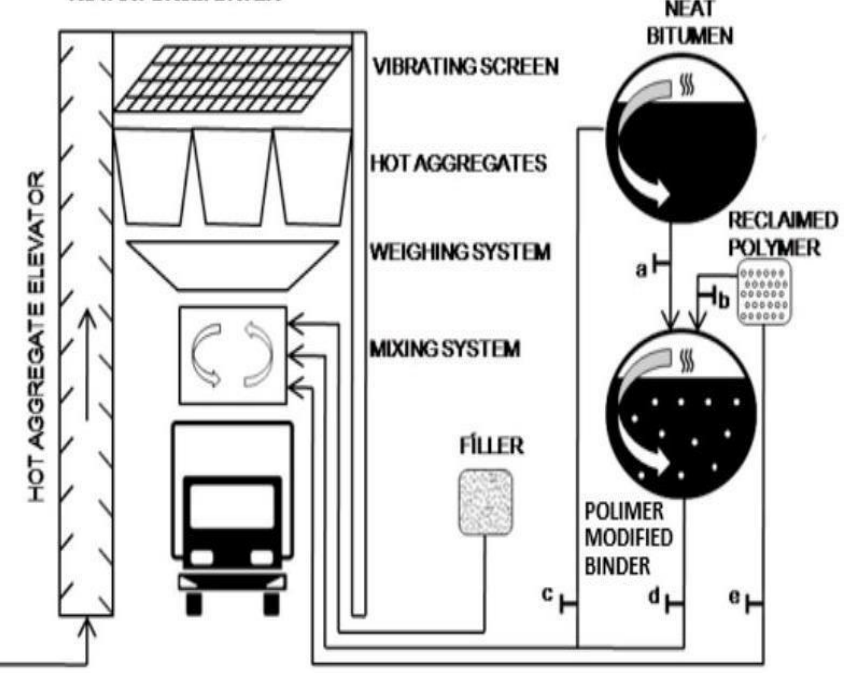

Fig. 6. Sketch of the wet and dry processes in an asphalt plant ii. Cleaning and shredding of waste plastic :- Plastic waste litter in the form of thin-film carry-bags, use-and-throw cups, PET bottles, etc. these are sorted, de-dusted, washed if necessary.

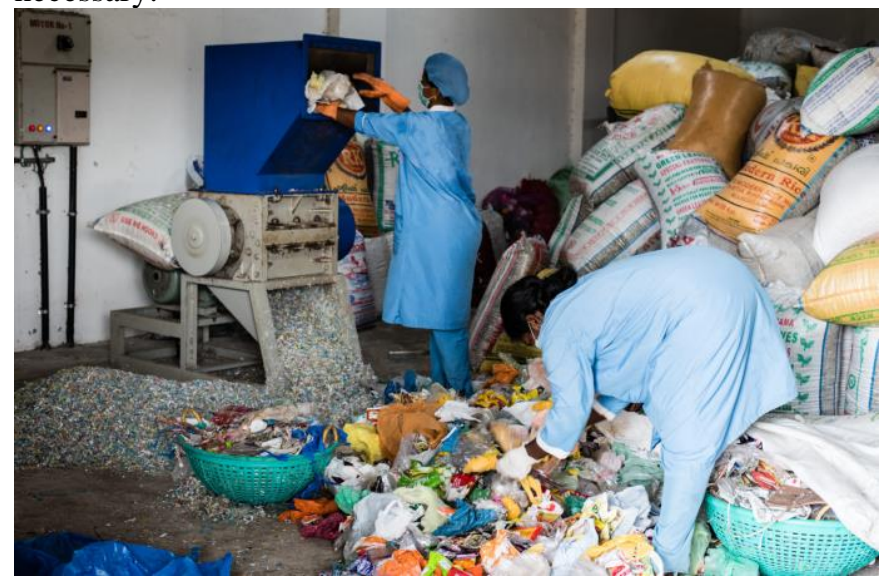

Fig. 7. Cleaning and shredding of waste plastic

iii. Shredding machine :- Plastic waste which is cleaned is cut into a size between $2.36 \mathrm{~mm}$ and 600 microns and of maximum size $2.36 \mathrm{~mm}$ length and $2.00 \mathrm{~mm}$ width using a shredding machine.

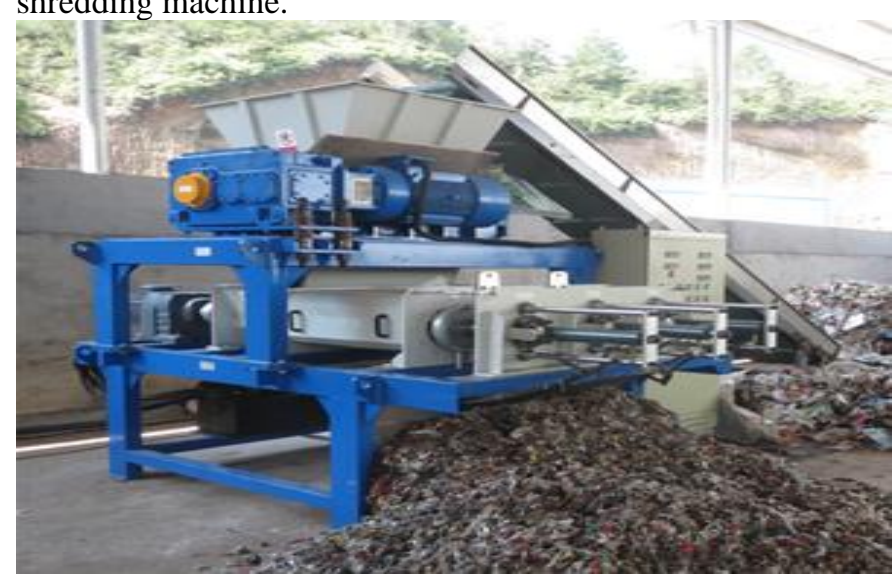

Fig. 8. Shredding machine

iv. Mixing of shredded waste plastic,aggregate and bitumen in central mixing plant :- The aggregate mix is heated to $135-170^{\circ} \mathrm{C}$ in a Central mixing plant. The requisite percentage of plastic waste to the weight of bitumen is injected with a pipe under compressed air in the drum of a drum mix plant through a pipe at $2 / 3$ length of the drum or through an opening over the pugmill in the case of a batch mix plant. The waste plastic initially coats the heated aggregates. In the next stage, bitumen is added to the aggregates, the temperature of the binder shall conform to the temperature depending on the grade of binder and the type of mix. The plastics waste coated aggregate is mixed with hot bitumen for 15 secs and the resulting mix transported for road construction. The central mixing plant helps to have better control of temperature and mixing of this material thus helping to have a uniform coating and heated bitumen is also sprayed. 


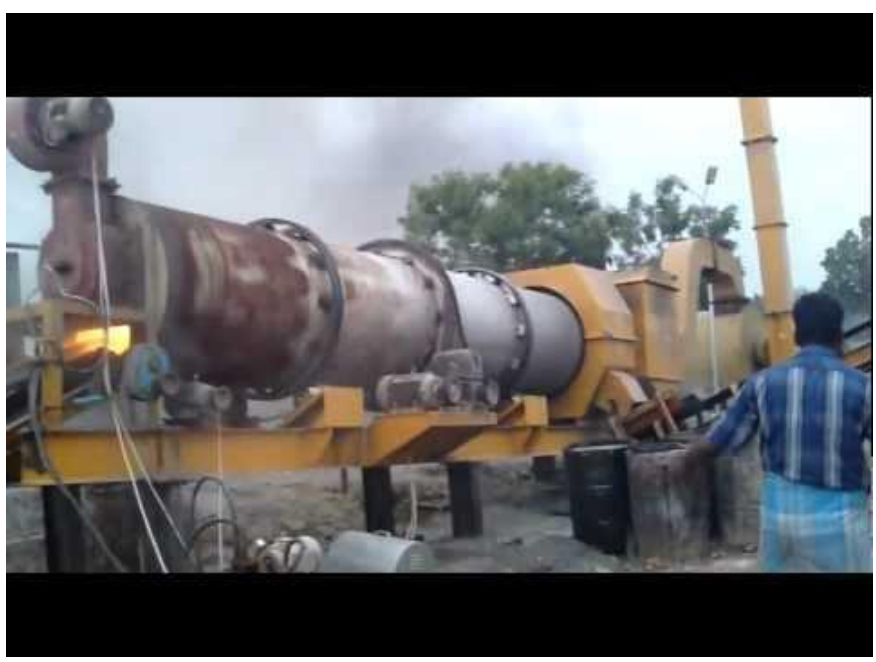

Fig. 9. Central mixing plant

v. Pavement and laying of bituminous mix :- The road laying temperature is between $110^{\circ} \mathrm{C}$ to $120^{\circ} \mathrm{C}$ for the waste plastic bituminous mix. The roller used, may be of any specified capacity.

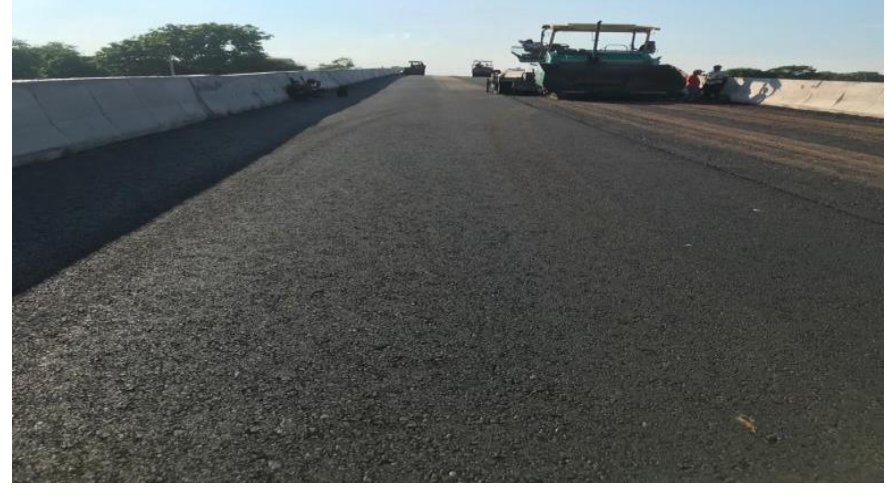

Fig. 10. Sketch of the wet and dry processes in an asphalt plant

\section{RESULT AND DISCISSION}

Dry process (Lab test-D.B.M II Grade)

- $\quad$ Plastic wastes are cleaned and dried (For ex: disposed carry bags, glasses etc) with a thickness of 60 microns is shredded into small pieces $(2.36 \mathrm{~mm}-4.75 \mathrm{~mm}$ size).

- $\quad$ Aggregate are weighed as shown in Figure 2 and are heated to $160^{\circ} \mathrm{C}$ in a pan.

TABLE IV. PHYSICAL PROPERTIES OF BITUMEN As Is 73 : 1992

\begin{tabular}{|l|c|c|c|}
\hline \multicolumn{1}{|c|}{ Designation } & Test result & Permissible limit & $\begin{array}{c}\text { Test } \\
\text { method }\end{array}$ \\
\hline $\begin{array}{l}\text { Specific gravity of } \\
\text { bitumen }\end{array}$ & 1.025 & $0.99 \mathrm{~min}$ & $\begin{array}{c}\text { IS: } 1202- \\
1978\end{array}$ \\
\hline $\begin{array}{l}\text { Softening point of } \\
\text { bitumen }\end{array}$ & $54.35^{\circ} \mathrm{C}$ & $47^{\circ} \mathrm{C}(\mathrm{min})$ & $\begin{array}{c}\text { IS: } 1205- \\
1978\end{array}$ \\
\hline $\begin{array}{l}\text { Flash point of } \\
\text { bitumen }\end{array}$ & $272^{\circ} \mathrm{C}$ & $220^{\circ} \mathrm{C}(\mathrm{min})$ & $\begin{array}{c}\text { IS: } 1209- \\
1978\end{array}$ \\
\hline $\begin{array}{l}\text { Fire Point of } \\
\text { Bitumen }\end{array}$ & $300^{\circ} \mathrm{C}$ & $270{ }^{\circ} \mathrm{C}(\mathrm{min})$ & $\begin{array}{c}\text { IS: } 1209- \\
1978\end{array}$ \\
\hline $\begin{array}{l}\text { Bitumen } \\
\text { Penetration Test }\end{array}$ & $50 \mathrm{~mm}$ & $45(\mathrm{~min})$ & $\begin{array}{c}\text { IS: } 1203- \\
1978\end{array}$ \\
\hline Ductility test & $94 \mathrm{~cm}$ & 100 & $\begin{array}{c}\text { IS: } 1208- \\
1978\end{array}$ \\
\hline
\end{tabular}

TABLE V.
\begin{tabular}{|c|c|c|c|c|}
\hline $\begin{array}{c}\text { Sieve } \\
\text { size }\end{array}$ & $\begin{array}{c}\text { Upper } \\
\text { limits }\end{array}$ & $\begin{array}{c}\text { Lower } \\
\text { limits }\end{array}$ & $\begin{array}{c}\text { Mid } \\
\text { limits }\end{array}$ & Result \\
\hline 37.5 & 100 & 100 & 100 & 100.00 \\
\hline 26.5 & 100 & 90 & 95 & 100.00 \\
\hline 19 & 95 & 71 & 83 & 93.89 \\
\hline 13.2 & 80 & 56 & 68 & 71.29 \\
\hline 4.75 & 54 & 38 & 46 & 42.69 \\
\hline 2.36 & 42 & 28 & 35 & 29.41 \\
\hline 0.3 & 21 & 7 & 14 & 10.53 \\
\hline 0.075 & 8 & 2 & 5 & 4.18 \\
\hline
\end{tabular}

\begin{tabular}{l}
\multicolumn{1}{|c|}{ TABLE VI. } \\
\begin{tabular}{|l|c|c|c|}
\hline \multicolumn{1}{|c|}{ AgGReGation } & $\begin{array}{c}\text { Test } \\
\text { result }\end{array}$ & $\begin{array}{c}\text { Permissible limit } \\
\text { (Morth } \\
\text { Specification) }\end{array}$ & Test method \\
\hline $\begin{array}{l}\text { Aggregate Impact } \\
\text { Value Test }\end{array}$ & 23.80 & Max 30\% & $\begin{array}{c}\text { IS: 2386 Part } \\
\text { IV }\end{array}$ \\
\hline $\begin{array}{l}\text { Specific Gravity } \\
\text { of Aggregates (20 } \\
\text { mm) }\end{array}$ & 2.68 & & $\begin{array}{c}\text { IS: 2386 Part } \\
\text { III }\end{array}$ \\
\hline $\begin{array}{l}\text { Specific Gravity } \\
\text { of Aggregates (10 } \\
\text { mm) }\end{array}$ & 2.71 & & $\begin{array}{c}\text { IS: 2386 Part } \\
\text { III }\end{array}$ \\
\hline $\begin{array}{l}\text { Specific Gravity } \\
\text { of Aggregates (6 } \\
\text { mm) }\end{array}$ & 2.69 & & $\begin{array}{c}\text { IS: 2386 Part } \\
\text { III }\end{array}$ \\
\hline $\begin{array}{l}\text { Specific Gravity } \\
\text { of Aggregates } \\
\text { (stone dust) }\end{array}$ & 2.74 & & $\begin{array}{c}\text { IS: 2386 Part } \\
\text { III }\end{array}$ \\
\hline $\begin{array}{l}\text { Stripping Value of } \\
\text { Aggregates }\end{array}$ & $45 \%$ & $5 \%$ & $\begin{array}{c}\text { Physical } \\
\text { appearance }\end{array}$ \\
\hline Water Absorption & 0.40 & Max 2\% & $\begin{array}{c}\text { IS: 2386 Part } \\
\text { III }\end{array}$ \\
\hline
\end{tabular}
\end{tabular}

\section{Marshall Sampling Mould}

The specifications of the Marshall sampling mould and hammer are given in table 7

TABLE VII. DIMENSIONS OF MARSHALL SAMPLING MOULD AND HAMMER

\begin{tabular}{|l|c|c|}
\hline \multicolumn{1}{|c|}{ Apparatus } & Value & Working tolerance \\
\hline \multicolumn{2}{|c|}{ Mould } \\
\hline $\begin{array}{l}\text { Average internal } \\
\text { diameter, mm }\end{array}$ & 101.2 & \pm 0.5 \\
\hline \multicolumn{2}{|c|}{ Hammer } \\
\hline Mass, kg & 4.535 & \pm 0.02 \\
\hline Drop height, mm & 457 & \pm 1.0 \\
\hline Foot diameter, mm & 98.5 & \pm 0.5 \\
\hline
\end{tabular}

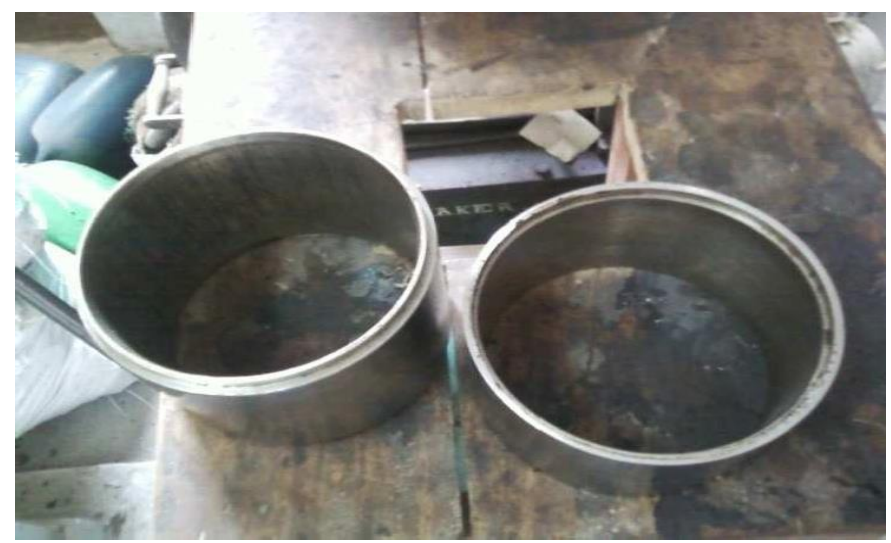

Fig. 11. Marshall sampling mould 


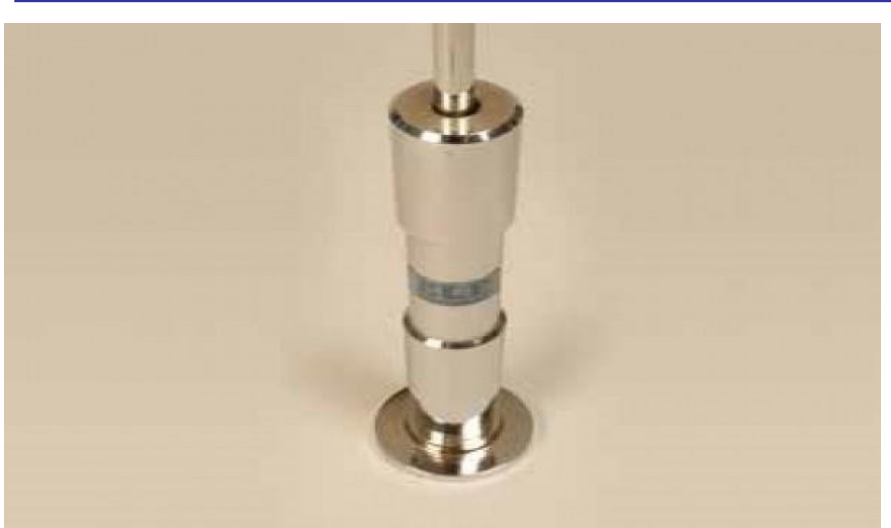

Fig. 12. Marshall hammer

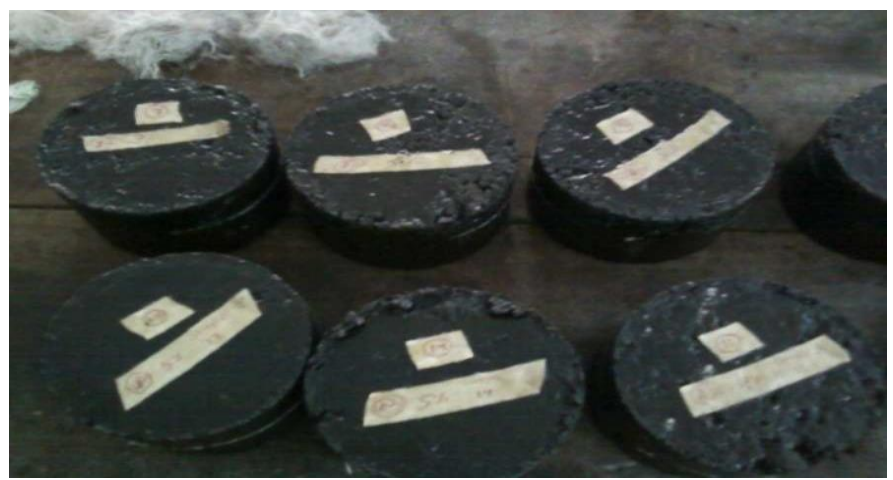

Fig. 13. Marshall sample

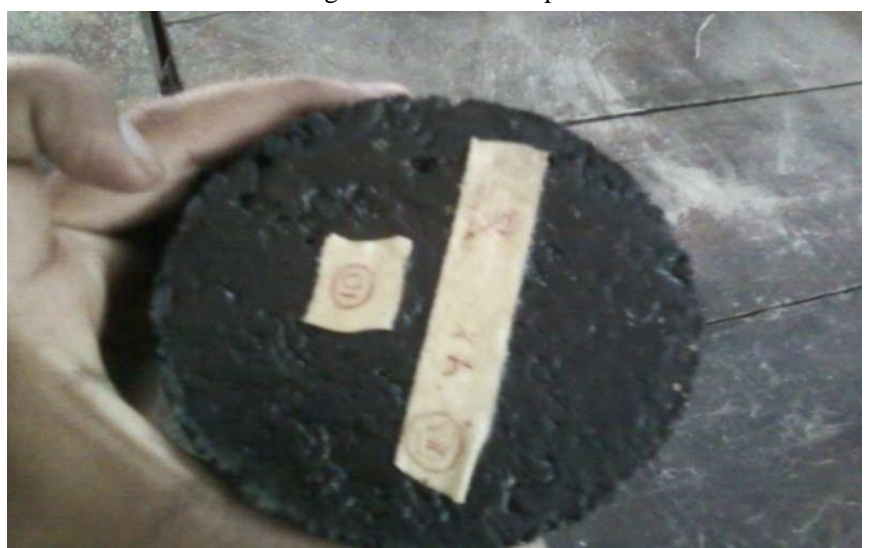

Fig. 14. Closer view of a marshall sample

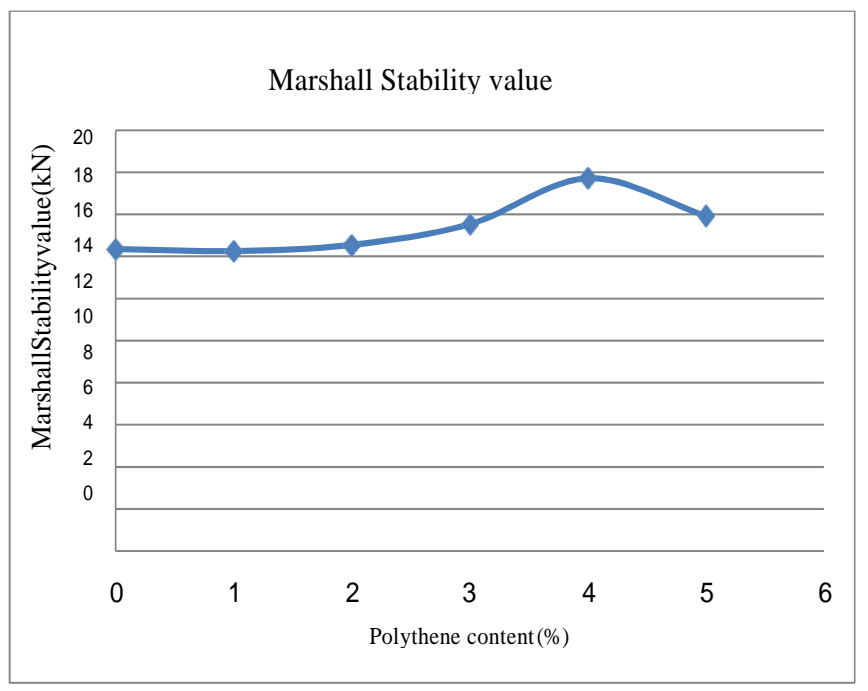

Fig. 15. Marshall stability value vs. polythene content

\section{CONCLUSION}

- Use of waste plastic in flexible pavements shows good result when compared with conventional flexible pavements.

- The polymer coated on aggregates reduces the voids and moisture absorption.

- The plastic pavement can withstand heavy traffic and also durable than flexible pavement.

- The use of plastic mix will reduce the bitumen content by $10 \%$ and increases the performance and strength of the road.

- It shows that with the increase of plastic waste in bitumen increases the properties of aggregate and bitumen.

- This technique is very eco-friendly as it uses the waste plastic which is being disposed in oceans, landfills etc.

\section{ACKNOWLEDGEMENT}

This piece of work would never be accomplished without God Almighty. For it is under his grace that I Live, learn and flourish. This report owes its existence to help, support and inspiration of our guide Amit Kumar Yadav, Assistant Professor \& Head, Department of Civil Engineering, J.S. University Shikohabad, Firozabad and Chhabi Lal Singh, Assistant Professor, Department of Civil Engineering, J.S. University Shikohabad, Firozabad.

I am also thankful to Devashish Chandra, Assistant Professor of Civil Engineering for their valuable suggestion, supports and encouragement during the course of my project work.

I am thankful to all staff members of Geotechnical Engineering Laboratory For their assistant and co- operation during the course of experimentation.

Also, thanks to The help and encouragement received from my friends, Salil, Abhishek, Sandeep, Devendra regarding the concepts and experimentations.

Last, but not the least, I would like to thank my loving parent for their encouragement and co-operation during the time of working through this project.

\section{REFERENCES}

[1] Vasudevan, R., Nigam, S.K., Velkennedy, R., Ramalinga, A., Sekar, C. and Sundarakannan, B. (2007) Utilization of Waste Polymers for Flexible Pavement and Easy Disposal of Waste Polymer.

[2] Vasudevan, R. (2004). "Use of plastic waste in construction of tar road." Environmental information system (Envis), Indian Centre for Plastics in the Environment.

[3] Indian Road Congress (2013). Guidelines for the Use of Waste Plastic in Hot Bituminous Mixes (Dry Process) In Wearing Courses. India.

[4] "Rheology and storage stability of modified binders with waste polymers composites." Road Materials and Pavement Design 20(4): 773-792.

[5] Utilization of Waste Plastic in Asphalting of Roads. Scientific Reviews \& Chemical Communications, 2, 147-157.

[6] L.R Schroceder, "The Use of Recycled Materials in Highway construction', Public Roads, Vol 58(Issue 2), 1994.

[7] Bahia, H.U. and Anderson, D.A., Strategic highway research program binder rheological parameters: Background and comparison with conventional properties. Transport. Res. Rec. 1488, 1995, 32, 39.Vasudevan R., Nigam S.K., Velkennedy R., Ramalinga Chandra Sekar A., Sundarakannan B. 
[8] Shankar, A., K. Koushik and G. Sarang (2013). "Performance studies on bituminous concrete mixes using waste plastics." Highway Research Journal 6(1).

[9] SaurabhTayde, Utilization Of Waste Plastic In Asphalting Of Roads, Department of Chemical Engineering College of Engineering and Technology, NH-6, Murtizapur Road, Babhulgaon (Jh) AKOLA -
444104 (M.S.) INDIA Department of Civil Engineering College of Engineering and Technology, NH-6, Murtizapur Road, Babhulgaon (Jh) AKOLA - 444104 (M.S.) INDIA.

[10] AvulaVamshi, Use of waste plastic in construction of Bituminous road, Journal of Engineering (JOE) ISSN: 2325-0224 